\title{
Application of Different Types of Lactic Acid Bacteria Inoculant on Ensiled Rice Straw; Effects on Silage Quality, Rumen Fermentation, Methane Production and Microbial \\ Population
}

Ehsan Oskoueian ${ }^{1}$, Saeid Jafari ${ }^{2}$, Reza Noura ${ }^{3}$, Mohammad Faseleh Jahromi ${ }^{4}$, Goh Yong Meng ${ }^{5}$, Mahdi Ebrahimi ${ }^{*}$

${ }^{1}$ Mashhad Branch, Agricultural Biotechnology Research Institute of Iran (ABRII), Agricultural Research, Education, and Extension Organization (AREEO), Mashhad, Iran

${ }^{2}$ Department of Veterinary Public Health, Faculty of Veterinary Science, Chulalongkorn University, Bangkok (10330), Thailand

${ }^{3}$ Department of Agriculture, Payame Noor University (PNU), Tehran, Iran

${ }^{4}$ Researches and Development Department, Ariana Biotech. Co., Mashhad, Iran

* Correspondence should be addressed to Mahdi Ebrahimi: mehdiebrahimii@gmail.com

${ }^{5}$ Department of Veterinary Preclinical Sciences, Faculty of Veterinary Medicine, University Putra Malaysia, Serdang, Selangor, Malaysia

(1)

1




\section{Abstract}

Bacterial inoculants are known to improve quality of silage. The objectives of the present study were to evaluate the effects of different types of lactic acid bacteria (LAB; L. plantarum, L. salivarius, $L$. reuteri, L. brevis and S. bovis) inoculation $\left(10^{6} \mathrm{~g}^{-1} \mathrm{DM}\right)$ on rice straw silage quality and to examine these effects on ruminal fermentation characteristics, digestibility and microbial populations in an in vitro condition. Inoculated rice straw was ensiled for 15 and 30 days. For in vitro study, rumen liquor was obtained from two rumen fistulated mature cows fed on mixed forage and concentrate at 60:40 ratio twice daily. Inoculation of $\mathrm{LAB}$ improved $(\mathrm{P}<0.05)$ the rice straw silage quality such as increased dry matter and crude protein contents, decreased $\mathrm{pH}$ and butyric acid, and increased propionic acid and LAB contents especially after 30 days of ensiling. Results from in vitro study revealed that addition of $\mathrm{LAB}$ to the rice straw silage improved fermentation characteristics such as increased total volatile fatty acids and dry matter digestibility $(\mathrm{P}<0.05)$. LAB treatments also decreased methane production and methane/total gas ratio after 15 and 30 days of ensiling. From the rumen microbial population perspective, cellulolytic, and fungal zoospores were enhanced while protozoa and methanogens were decreased by the LAB treatments. Based on these results, it could be concluded that inoculating rice straw silage with LAB (especially for L. plantarum and S. bovis) improved silage quality, rumen fermentation parameters and microbial populations in vitro. However, in vivo studies need to confirm those effects.

Keywords: in vitro, lactic acid bacteria, methane, microbial population, rice straw silage, rumen. 
Introduction

60 Use of agricultural by-products is increasing because of limitations in food sources for livestock

which result in economic and environmental concerns. Rice straw, a major agricultural by-product, is

routinely utilized as a food source for ruminants in many regions of East and South-East Asia (Zhang

et al., 2017). In Malaysia, rice straw is one of the most abundant agricultural by-products (Ghazali et

al., 2013). However, rice straw has very low nutritive values with low crude protein content and

metabolic energy for ruminants. Technologies to create high-quality animal feed from agricultural

residues need to be developed. Ensiling is a practical way to utilize water-soluble carbohydrates by

lactic acid bacteria (LAB) under anaerobic conditions to produce organic acids such as lactic acid to

reduce $\mathrm{pH}$ and to inhibit the growth of harmful bacteria resulting in good quality silage (He et al.,

2018). Silage feeding is also a way of enhancing livestock production in the tropics especially during

periods of inadequate supply of fresh forage. According to the literature, LAB (homofermentative

and heterofermentative) which are widely used as inoculants, increased the concentration of lactic

acid while lowered the $\mathrm{pH}$ and the concentration of $\mathrm{NH}_{3}-\mathrm{N}$ in silage (Silva et al., 2016). Several

studies have shown the effectiveness of LAB on the feed quality of rice straw (Zhang et al., 2010;

Cao et al., 2013; LIU et al., 2015; Oladosu et al., 2016). Besides, those studies mentioned that adding

LAB increased the lactic acid content of silage, increased dry matter digestibility, improved in vitro

ruminal fermentation parameters and decreased ruminal methane production. However, not all in

vitro studies have reported reductions in methane production (Contreras-Govea et al., 2011).

It has been hypothesized that LAB silage inoculants could reduce methane emissions from ruminants by several modes of action; changes in the chemical composition of the silage, interaction of LAB with rumen microbes and alteration of rumen fermentation (EllIS et al., 2016). Methane, as produced from anaerobic fermentation in the rumen, accounts for $2-12 \%$ loss of dietary gross energy in 
production not only improves the efficiency of nutrient utilization in ruminants but also helps to

protect the environment from the negative consequences of global warming.

86 From the microbiological perspective, some studies indicated that the inclusion of silage alone

87 (Nguyen et al., 2017) as well as silage + LAB inoculant (He et al., 2018) could improve microbial population in the rumen. However, to the best of our knowledge, there is still limited information on the effect of different types of LAB inoculated rice straw silage on microbial population responses. Therefore, the purpose of this experiment was to test the rumen microbial populations and

91 fermentation characteristics as well as testing methane mitigation potential of rice straw silage inoculated with different types of LAB in an in vitro condition.

\section{Materials and Methods}

The protocol for the experimental procedures were reviewed and approved by the Animal Care and

Use Committee of the University of Putra in Malaysia.

\section{Isolation, identification and characterization of LAB}

97 Cecal contents from healthy adult, commercial broiler chickens and rumen samples from fistulated male cattle (body weight: $209 \mathrm{~kg}$ ) were used for the isolation of LAB. 1 gram of each samples were dissolved in $9 \mathrm{ml}$ of peptone water $(0.01 \%)$ and shaken at $200 \mathrm{rpm}$ for $10 \mathrm{~min}$. Several dilution from each sample $\left(10^{-3}\right.$ to $\left.10^{-7}\right)$ were prepared into dilution tube containing peptone water $(0.01 \%) .100 \mu 1$ of each dilution were transferred into the plate containing MRS Rogosa agar (Oxoid CM 627, Hampshire, UK) as selective medium for LAB (Ebrahimi, 2012). Plates were anarobically incubated of 80 isolates were selected and tested for Gram stain, hydrogen peroxidase and lactic acid production. The LAB strains that actively produced lactic acid were chosen for the molecular identification. 


\section{Molecular identification}

DNA of selected LAB was extracted using DNA extraction kit (QIAamp Blood and Tissue Kit, Qiagen, Hilden, Germany). The amplification of 16SrRNA genes were conducted using 27F 5'AGAGTTTGATCCTGGCTCAG-3' and 1492R- 5'-GGCTACCTTGTTACGACTT-3'primers. The PCR amplification was performed with i-StarTaq DNA polymerase kit (iNtRON Biotechnology, Sungnam, Kyungki-Do, Korea) using $1 \mu \mathrm{l}$ of a template $\left(10 \mathrm{ng} \mu \mathrm{l}^{-1}\right)$ in $20 \mu \mathrm{l}$ of reaction solution. Amplification was performed using a BIORAD MyCycler ${ }^{\mathrm{TM}}$ thermal cycler with the following program: 1 cycle at $94^{\circ} \mathrm{C}$ for $4 \mathrm{~min}, 30$ cycles of $94^{\circ} \mathrm{C}$ for $1 \mathrm{~min}, 55^{\circ} \mathrm{C}$ for $30 \mathrm{~s}, 72^{\circ} \mathrm{C}$ for 2 min and a final extension at $72^{\circ} \mathrm{C}$ for $5 \mathrm{~min}$. The PCR products were mixed with loading dye and loaded on to a 1.0\% SeaKem ${ }^{\circledR}$ GTG ${ }^{\circledR}$ agarose (FMC BioProducts, Rockland ME, USA) containing ethidium bromide, and electrophoresis was carried out at $90 \mathrm{~V}$ for $1 \mathrm{~h}$. The PCR products were visualized under UV illumination and excised from the gel and the PCR product was extracted using MEGAquick-spin PCR \& Agarose Gel Extraction kit (iNtRON Biotechnology). PCR product was sequenced using forward and reverse primers ( $1^{\text {st }}$ Base Co., Malaysia). The contig was done for the forward and reverse sequences of each isolates by contig assembly program of Bioedit software and then sequences were analyzed by the Bellerophon and Mallard program to remove chimeric rDNA clones. Approximately $1400 \mathrm{bp}$ segment of the 16S rRNA gene of the isolates were blast using National Center for Biotechnology Information (NCBI) library with the following address: http://blast.ncbi.nlm.nih.gov/Blast.cgi.

\section{Rice straw ensiling and inoculating procedures}

Fresh rice straws used in this experiment were harvested in the fields of the Malaysian Agricultural Research and Development Institute (MARDI) located in Serdang, Selangor, Malaysia $\left(3^{\circ} 00^{\prime} 18.88^{\prime \prime} \mathrm{N}, 101^{\circ} 42^{\prime} 15.05^{\prime \prime} \mathrm{E}\right)$. Then, they were chopped to $8-10 \mathrm{~cm}$ long pieces with a laboratory chopper. Five isolates of LAB (L. plantarum, L. salivarius, L. reuteri, L. brevis, and S. 
bovis) were used for inoculation and the inoculation rate was based on the numbers of colonyforming units per gram in the inoculant powders. The dry matter of chopped rice straw was determined and the inoculants were applied by suspending the appropriate weight of inoculant powder in required amount of water to increase the moisture content of rice straw to $70 \%$ and spraying it over $2 \mathrm{~kg}$ batches of rice straw and mixed thoroughly. Each treatment contained $10^{6} \mathrm{cfu} / \mathrm{g}$ $\mathrm{DM}$ of LAB inoculants. The treated rice straw was ensiled in $500 \mathrm{~mL}$ Scott bottle. There were 3 bottles per inoculant treatment of each of the silages. The silages were stored for 15 and 30 days at room temperature $\left(28\right.$ to $\left.32^{\circ} \mathrm{C}\right)$. Control silages were also prepared at the same time with sterile water.

\section{Chemical analyses and fermentation quality for rice straw silage}

After 15 and 30 days of ensiling, bottles of the untreated and inoculated silages were opened for analyzing chemical analyses and fermentation quality. $20 \mathrm{~g}$ of representative silage were mixed with $180 \mathrm{~g}$ sterile water in a laboratory blender (Waring, New Hartford, Conn, USA) for 2 minutes. The extract was filtered through four layers of gauze and no. 1 filter paper (Whatman, Inc., Clifton, NJ). The filtrate extract was used for measuring Dry matter (DM), Crude protein (CP), neutral detergent fiber (NDF), acid detergent fiber $(\mathrm{ADF}), \mathrm{NH}_{3}-\mathrm{N}, \mathrm{pH}, \mathrm{LAB}$ population, lactic acid, and volatile fatty acids (VFA). The DM and CP (total nitrogen $\times 6.25$ ) were contents determined using method number 934.1 and 990.03 (AOAC, 1990), respectively. NDF and ADF were determined according to Van Soest and coworkers (Van Soest et al., 1991). The concentration of $\mathrm{NH}_{3}-\mathrm{N}$ was determined as described in our previous work (Jafari et al., 2016). The pH was determined using a pH electrode (Mettler-Toledo Ltd., England). Lactic acid and volatile fatty acids were determined using gas-liquid chromatography with Quadrex 007 Series (Quadrex Corporation, New Haven, CT 06525 USA) bonded phase fused silica capillary column $(15 \mathrm{~m}, 0.32 \mathrm{~mm}$ ID, $0.25 \mu \mathrm{m}$ film thickness) in an Agilent 7890A gas-liquid chromatography (Agilent Technologies, Palo Alto, CA, USA) equipped with a flame ionization detector (FID). The total number of LAB in the silage was determined on 
MRS Rogosa agar as described above with the plate count method (Ebrahimi, 2012). Colonies were counted from the plates at appropriate dilutions and the number of colony forming units (CFU) was expressed as $\log 10$ per gram of rice straw.

\section{In vitro rumen fermentation and digestibility}

Two rumen fistulated mature cows were fed (Table 1) at maintenance level on mixed forage and concentrate at 60:40 ratio twice daily. Rumen liquor was collected before the morning feed from both fistulated cows and strained through four layers of muslin gauze into a pre-warmed bottle at $39^{\circ} \mathrm{C}$. Treated and untreated rice straw used as substrates. A total of six syringes for each treatment were used for in vitro study. The contents of three syringes were used for in vitro dry matter digestibility (IVDMD), fermentation parameters and the remaining three syringes were used for rumen microbial population quantification. $500 \mathrm{mg}$ of substrate were weighed into $100 \mathrm{ml}$ calibrated glass syringes. The incubation medium was prepared as described by our previous work (Jafari et al., 2017) and $40 \mathrm{ml}$ was dispensed anaerobically into each syringe. Syringes were incubated at $39^{\circ} \mathrm{C}$ for

$24 \mathrm{~h}$. In vitro gas production was measured in triplicate at 2, 4, 8, 12 and 24 . In each incubation run, three blanks were used as blank to correct the values for gas released from the substrates. Cumulative gas production data were fitted in NEWAY Excel Version 5.0 package (Ørskov and McDonald,

172 1979). The above procedures were conducted in three individual runs. After $24 \mathrm{~h}$ of fermentation, 173 IVDMD of substrates was determined by the contents of syringes. The fermentation end products 174 (e.g. $\mathrm{pH}, \mathrm{NH}_{3}-\mathrm{N}$ and VFA) and the number of $\mathrm{LAB}$ were also determined as described earlier.

\section{Quantification of rumen microbial population by real-time PCR}

The targeted microbes were cellulolytic bacteria such as Fibrobacter succinogenes, Ruminococcus albus, Ruminococcus flavefaciens, general bacteria, general anaerobic fungi, total protozoa, total methanogens and total archaea. DNA was extracted from $300 \mu 1$ of fermented rumen content (fluid and digesta from three syringes) by QIAGEN DNA Mini Stool Kit (QIAGEN, Valencia, CA) 
according to manufacturer's recommendations. Then the PCR product was purified using a QIA quick PCR purification kit (QIAGEN, Inc., Valencia, CA) and cloned to the plasmid. The target

DNA was quantified by using serial 10 -fold dilutions from $10^{1}$ to $10^{8}$ DNA copies of the previously quantified DNA purified plasmid. Microorganisms and sequences of the primers used in this study are shown in Table 2.

\section{Statistical analyses}

Data were analyzed using the general linear (GLM) models procedure of SAS (SAS, 2003) in a completely randomized design and the means were compared with Duncan's Multiple Range test. Differences of $\mathrm{P}<0.05$ were considered to be significant.

\section{Results}

\section{Chemical analyses and fermentation quality of rice straw silage}

191 The contents of DM, CP, ether extract, NDF, ADF were affected $(\mathrm{P}<0.05)$ by the treatments (Table 3). The DM contents were numerically decreased as the duration of ensiling increased. The control group had higher DM content as compared with the LAB treatments at 15 and $30 \mathrm{~d}$ of ensilage. The $\mathrm{CP}$ content was greater in LAB treatments as compared with control (10.9-12.7 vs 9.5, respectively). The NDF and ADF of the LAB treatments were less than those of the control (Table 3 ). However, the gross energy was not affected $(\mathrm{P}>0.05)$ by the treatments. Analysis of sugar in fermented rice straw showed significant decrease $(\mathrm{P}<0.05)$ in the concentration of glucose and fructose among LAB treatments as compared with the control.

The value of $\mathrm{pH}$ decreased in all treatments except for control as the duration of ensiling increased (from $15 \mathrm{~d}$ to $30 \mathrm{~d}$ ). The LAB treatment groups showed the lowest $\mathrm{pH}$ value as compared with control throughout the ensiling period with $\mathrm{pH}$ values between 4.3- 5.3. Lactic acid content (mM) increased from days 15 to 30 among all treatments; however, LAB treatments were significantly 
higher than that of control. Among the LAB treatments, L. plantarum and S. bovis had the highest lactic acid content at $30 \mathrm{~d}$ of ensilage (36.9 and 35.7, respectively). The acetic acid and propionic

acid contents of all treatments increased with the increase in duration of ensiling. Again, $L$. plantarum and S. bovis showed the greatest values for acetic and propionic acids at $30 \mathrm{~d}$ of ensilage

(24.1 and 2.9 vs 22.5 and $2.5 \mathrm{mM}$, respectively). Butyric acid content showed a decreasing trend among the treatments as the duration of ensiling increased, with the highest value for the control (5.5 and $4.6 \mathrm{mM}$ at 15 and $30 \mathrm{~d}$ of ensilage, respectively). As compared with the control, LAB treatments didn't show significant differences $(\mathrm{P}>0.05)$ in terms of $\mathrm{NH}_{3}-\mathrm{N}$ concentration (average: $0.049 \%$ ).

The analysis of the LAB content $(\log \mathrm{cfu} / \mathrm{g})$ showed that the LAB treatments exhibited a significant $(\mathrm{P}<0.05)$ difference and increase as compared with control (Table 4).

\section{In vitro rumen fermentation characteristics, methane production and DM digestibility}

214 According to the data of in vitro (Table 5), LAB treatments had less $(\mathrm{P}<0.05)$ gas production at $24 \mathrm{~h}$ of fermentation as compared with control. Conversely, coefficient of degradable $B$ fraction was greater in LAB treatments especially for L. plantarum and S. bovis (at $30 \mathrm{~d}$ of ensilage) as compared with control. However, coefficients of rapidly degradable $a$ fraction and $c$ (degradation rate of degradable $b$ fraction) were not affected $(\mathrm{P}>0.05)$ by the treatments. The LAB treatments especially for L. plantarum and $S$. bovis at $30 \mathrm{~d}$ of ensiling had greater $(\mathrm{P}<0.05)$ amounts of IVDMD as compared with control. Total VFA and acetic acid was also greater $(\mathrm{P}<0.05)$ among LAB treatments.

The concentration of $\mathrm{NH}_{3}-\mathrm{N}$ and $\mathrm{pH}$ were almost similar among the treatments with no significant difference $(\mathrm{P}>0.05)$. Methane production and methane/total gas significantly $(\mathrm{p}<0.05)$ decreased between LAB treatments compared with control groups. L. plantarum at 15 and $30 \mathrm{~d}$ of ensiling exhibited respectively $46 \%$ and $48 \%$ of $\mathrm{CH}_{4}$ reduction as compared with control. 


\section{In vitro rumen microbial populations}

228 LAB treatments had greater $(\mathrm{P}<0.05)$ total bacteria and fungi at $24 \mathrm{~h}$ of fermentation as compared 229 with control (Table 6). Conversely, control had greater $(\mathrm{P}<0.05)$ total protozoa, methanogens and 230 archaea at the end of in vitro fermentation. Butyrivibrio fibrisolvens and Ruminococcus 231 flavafaciences was lower for control as compared with LAB treatments at 15 and 30 days of silage. 232 Especially, L. plantarum and S. bovis at $30 \mathrm{~d}$ of silage had the greatest populations of mentioned 233 bacteria. Fibrobacter succinogenes was also almost similar among LAB treatments but higher $234(\mathrm{P}<0.05)$ than control group.

\section{Discussion}

\section{Chemical composition and fermentation characteristics}

237 Inoculating the different types of $\mathrm{LAB}$ for ensiled rice straw increased $\mathrm{CP}$ content in the current study. Our results were consistent with the results of Liu et al. (2015) which evaluated the effects of fermentation using LAB culture broth on the feed quality of rice straw. However, our results are contradictory to their results in terms of $\mathrm{NH}_{3}-\mathrm{N}, \mathrm{NDF}$ and ADF contents. The LAB treatments in the current study did not affect $\mathrm{NH}_{3}-\mathrm{N}$ concentration after 15 and 30 days of ensiling. High lowers silage quality (Jafari et al., 2018). Lower NDF and ADF contents among the LAB treatments compared with the control group in this study could be the result of the lower level of heat damage on protein which improves energy content (Saha et al., 2010) as shown in Table 3. Chen et al. (2019) mentioned that lower NDF content in silages could also be due to the loss of hemicellulose occurred in the ensiling process. This loss could be due to a combination of enzymatic and acid hydrolysis of the more digestible cell wall fractions during the fermentation. DM is the remaining materials after the removal of water and contains the main nutrients for animal consumption. 
current study, inoculations of different LAB decreased the DM loss which could be due to inhibiting the clostridia and aerobic bacteria (Ni et al., 2015). The lack of DM loss in our study was also consistent with the application of LAB isolated from forage paddy rice silage in China (Ni et al., 2015).

The previous studies showed that bacterial inoculation of silage could convert the composition of cell-wall carbohydrates into organic acids and cause a decrease in $\mathrm{pH}$ during fermentation (Baek et al., 2017). In the current study, $\mathrm{pH}$ decreased with increase in the duration of ensiling among the LAB treatments (especially for L. plantarum and S. bovis) which was consistent with those in the literature. Silage $\mathrm{pH}$ (the lower the better) is one of the main factors depicting the extent of fermentation and quality of ensiled forage (Chen et al., 2019). The lower $\mathrm{pH}$ among LAB treatments (4.99) VS control (5.6) suggests good fermentation. Consistently, Kim et al. (2017) indicated that $L$. plantarum inoculant for fresh rice straw silage decreased the $\mathrm{pH}$, acetic acid, $\mathrm{NH}_{3}-\mathrm{N}$, and butyric acid contents (Kim et al., 2017). However, in our study, LAB treatments improved acetic acid with no effect on butyric acid content. A high concentration of butyric acid is the sign of protein degradation and DM loss as well as energy wastage (Oladosu et al., 2016). Kim et al. (2017) also concluded that adding L. plantarum could improve the fermentation quality and feed value of rice straw silage. Inoculation of the mixture of corn steep liquor and air-dried rice straw with homo fermentative (L. plantarum) and hetero-fermentative (L. plantarum, Lactobacillus casei, and Lactobacillus buchneri) LAB significantly increased the concentration of acetic acid and lactic acid compared with the control in a study conducted in China (Li et al., 2016). Our results were also consistent with that study in terms of increased acetic acid and lactic acid contents. High

272 concentration of lactic acid results in lower $\mathrm{pH}$ (as observed in this study) which inhibits the growth and activities of undesirable bacteria during silage (Oladosu et al., 2016). Acetic acid also possesses antifungal activity which reduces the spoilage of organisms in ensiled mass and improves the

275 fermentation quality of silages. Zhang et al. (2010) mentioned that chopping rice straw before 
ensiling could enhance the lactic acid concentration and total VFA content. The improved criteria

277 observed in our study could also be due to chopping the rice straw before ensiling. Li et al. (2016) also demonstrated that homo fermentative and hetero-fermentative LAB could effectively improve

279 the fermentation quality of the silage. Rice straw, a by-product of rice production which could be abundantly found in Southeast Asia which is the most important rice-producing region in the world (Zhang et al., 2010). Thus, by improving the nutritive value of this by-product through processes such as ensiling and inoculating beneficial microbes, farmers could overcome the limitations of feed sources in many parts of the tropics.

\section{In vitro rumen fermentation characteristics, methane production and DM digestibility}

Some studies have reported the effectiveness of LAB inoculation on in vitro ruminal fermentation characteristics (Zhang et al., 2016; Baek et al., 2017; Zhang et al., 2017). Lack of effect on rumen pH and $\mathrm{NH}_{3}-\mathrm{N}$ after 15 and 30 days of ensiling among the LAB treatments in this study was contrary to the results of Zhang et al. (2010). They reported that three levels of LAB inoculants (LAB; $2 \times 10^{5}$, $3 \times 10^{5}$ and $4 \times 10^{5} \mathrm{cfu} / \mathrm{g}$ fresh forage) on rice straw (whole and chopped rice straw) silage decreased

$\mathrm{pH}, \mathrm{NH}_{3}-\mathrm{N}$ and acetic acid concentrations in Holstein dairy cows. Our results were consistent with

theirs in terms of total VFA and propionic acid concentrations which showed respectively increase and decrease among the LAB treatments. Zhang et al. (2010) also concluded that the chopping process and LAB addition improved the silage quality of rice straw, and its partial substitution with corn silage could lower the cost of the dairy cow ration with no negative effects on lactation

performance. Supplementing rice straw and sugar beet leaf silage treated with lactic acid bacteria enhanced performance and productivity of lactating Frisian cows in an in vivo study (El Tawab et al., 2017). Another in vivo study showed improved fermentation quality, as well as improved digestibility of feed components after feeding wethers with urea treated rice straw silage with LAB (Fang et al., 2012). In this study, the LAB treatments especially for L. plantarum and S.bovis showed the highest IVDMD and the lowest methane production. Different results obtained among variant 
types of LAB in this study were consistent with Ellis et al. (2016) which showed that organic matter digestibility, gas and methane production vary with type of LAB added and type of substrate incubated. Our results were consistent with the previous studies and the results of Cao et al. (2013) in

which vegetable residue silage inoculated with $L$. plantarum showed the highest IVDMD and lowest

methane production. Methane is a by-product of the anaerobic fermentation of dietary carbohydrates in the rumen, and methanogenesis possesses a biological regulatory mechanism for animal health (Chen et al., 2017). However, Jafari et al. (2016) mentioned that methane formation is a contributing factor for the atmospheric burden of green-house gases, which is linked to the global warming and climate change as well as a significant energy loss for animal due to the exit of carbon.

\section{In vitro rumen microbial populations}

311 The growing public concern over the widespread use of antibiotics in livestock production and the emergence of antibiotic-resistant bacteria has stimulated interest in developing alternatives that promote animal performance and health. One potential alternative is the use of direct-fed microbials as feed additives to thrive in the gastrointestinal tract and prevent the establishment of pathogens (Jiao et al., 2017). LAB as a particular type of direct-fed microbials as well as LAB silage inoculants has exerted probiotic effects resulted in improvement in ruminant performance (Weinberg et al., 2016). In the current study, microbial populations were affected by the LAB treatments. Fibrobacter succinogenes, Ruminococcus flavefaciens and Ruminococcus albus which are the most predominant cellulolytic bacterial species in ruminants were highest among the LAB treatments. Jiao et al. (2016) reported about the beneficial effect of $\mathrm{LAB}$ on fiber digestion which could be due to the competition with the efficient lactate-producing rumen microorganisms on essential compounds. This competition might reduce the rate of lactate production by rumen bacteria which results in higher activity of cellulolytic rumen populations. Our results were in agreement with the previous study (Nguyen et al., 2017). According to Nguyen et al. (2017), dairy steers receiving rice straw and

Leucaena silage enhanced rumen microbial population (especially cellulolytic), and fungal 
population as well. They mentioned a decrease in the protozoal populations by the increase in the level of Leucaena silage. We also found decreases in the protozoal and methanogen populations by

the LAB treatments. Jafari et al. (2018) reported that protozoa can provide electrons as a source of

$\mathrm{H}_{2}$ to the methanogens, and hence, antiprotozoal effects of feedstuff could decrease methane

production by methanogens attached to protozoa. Moreover, fungal populations were increased in our studies among the LAB treatment groups. Nguyen et al. (2017) indicated that there was an increase in the numbers of fungal when protozoa have been removed from the rumen. They also mentioned that Leucaena silage could provide adequate nitrogen source for microbial growth leading

to the increase in the bacterial population which could be the case for our result's. Consistent to our study, total mixed rations containing corn silage and/or grass silage increased total bacteria and

Fibrobacter succinogenes in dairy cows (Lengowski et al., 2016). B. fibrisolvens which are involved in rumen fatty acid biohydrogenation were greater among LAB treatments in this study. Conjugated linoleic acid which has beneficial biological effects in animal models is formed as an intermediate during biohydrogenation of linoleic acid to stearic acid in the rumen by mainly $B$. fibrisolvens and other rumen bacteria (Ebrahimi et al., 2018).

\section{Conclusions}

342 In conclusion, inoculation of Lactobacillus $\left(10^{6} \mathrm{~g}^{-1} \mathrm{DM}\right)$ in rice straw silage improved the silage 343 quality (e.g high CP content) and fermentation characteristic (e.g. increase in production of lactic 344 acid and acetic acid) in the silage. Among inoculated LAB, L. plantarum and S. bovis were found to 345 be more potent for the fermentation. In vitro rumen digestibility test showed higher rumen 346 digestibility, higher VFA production and lower methane production in the rice straw fermented with 347 LAB particularly with L. plantarum and S. bovis. Moreover, analysis of rumen microbial population showed significant increases in the populations of cellulolytic bacterial (Fibrobacter succinogenes, Butyrivibrio fibrisolvens and Ruminococcus flavafaciences), protozoa, methanogens and archaea among the LAB treatments as compared with control. Overall, L. plantarum, S. bovis were found to 
bioRxiv preprint doi: https://doi.org/10.1101/612556; this version posted April 17, 2019. The copyright holder for this preprint (which was not certified by peer review) is the author/funder, who has granted bioRxiv a license to display the preprint in perpetuity. It is made available under aCC-BY 4.0 International license.

be more promising to be applied in rice straw fermentation; however, in vivo experiments need to

confirm these results.

\section{Acknowledgment}

The authors would like to thank the faculty of Veterinary Medicine, University of Putra in Malaysia as well as Ratchadapisek Somphot Fund for Postdoctoral Fellowship in Chulalongkorn University.

\section{Conflict of interests}

None.

\section{References}

AOAC 1990. AOAC. Official methods of analysis of the Association of Official Analytical Chemists. Vol 1. In: The Association.

Baek YC, Kim MS, Reddy KE, Oh YK, Jung YH, Yeo JM and Choi H 2017. Rumen fermentation and digestibility of spent mushroom (Pleurotus ostreatus) substrate inoculated with Lactobacillus brevis for Hanwoo steers. Revista Colombiana de Ciencias Pecuarias. 30(4): 267-277.

Cao Y, Cai Y and Takahashi T 2013. Ruminal digestibility and quality of silage conserved via fermentation by lactobacilli. In: Lactic Acid Bacteria-R \& D for Food, Health and Livestock Purposes. InTech.

Chen L, Ren A, Zhou C and Tan Z 2017. Effects of Lactobacillus acidophilus supplementation for improving in vitro rumen fermentation characteristics of cereal straws. Italian Journal of Animal Science. 16(1): 52-60.

Chen L, Yuan X, Li J, Dong Z, Wang S, Guo G and Shao T 2019. Effects of applying lactic acid bacteria and propionic acid on fermentation quality, aerobic stability and in vitro gas production of forage-based total mixed ration silage in Tibet. Animal Production Science. 59(2): 376-383.

Contreras-Govea FE, Muck RE, Mertens DR and Weimer PJ 2011. Microbial inoculant effects on silage and in vitro ruminal fermentation, and microbial biomass estimation for alfalfa, bmr corn, and corn silages. Animal Feed Science and Technology. 163(1): 2-10.

Ebrahimi M 2012. Production of Omega-3 Polyunsaturated Fatty Acid-entiched Chevon Using Treated Oil Palm (Elaesis Guineensis Jacq.) Frond Silage. Universiti Putra Malaysia.

Ebrahimi M, Rajion MA, Jafari S, Jahromi MF, Oskoueian E, Sazili AQ, Goh YM and Ghaffari MH 2018. Effects of dietary n-6: n-3 polyunsaturated fatty acid ratios on meat quality, carcass characteristics, tissue fatty acid profiles, and expression of lipogenic genes in growing goats. PloS one. 13(8): $\mathrm{e} 0188369$.

El Tawab AMA, Hassan AAM, Khattab MSAE, Matloup OH, Farahat ESA, Khalel MS, Morsy TA and Fouad MT 2017. Productive performance of lactating frisian cows fed sugar beet leaves silage treated with lactic acid bacteria. International Journal of Zoological Research. 13: 74-82.

ElIIS J, BANNINK A, HINDRICHSEN I, KINIEy R, PElIIKAAN W, MIIORA N and DIJKSTRA J 2016. Effect of lactic acid bacteria inoculants on in vitro rumen organic matter digestibility, total gas and methane production. Animal Feed Science and Technology. 34-39.

Fang J, Matsuzaki M, Suzuki H, Cai Y, Horiguchi Ki and Takahashi T 2012. Effects of lactic acid bacteria and urea treatment on fermentation quality, digestibility and ruminal fermentation of roll bale rice straw silage in wethers. Grassland science. 58(2): 73-78. 
bioRxiv preprint doi: https://doi.org/10.1101/612556; this version posted April 17, 2019. The copyright holder for this preprint (which was not certified by peer review) is the author/funder, who has granted bioRxiv a license to display the preprint in perpetuity. It is made available under aCC-BY 4.0 International license.

Ghazali H, Wan M and Wan Z 2013. Effects of inoculating Lactobacillus plantarum, molasses and urea on the fermentation of whole crop rice silage. Malaysian Journal of Animal Science. 16(2): 75-82.

He L, Zhou W, Wang Y, Wang C, Chen X and Zhang Q 2018. Effect of applying lactic acid bacteria and cellulase on the fermentation quality, nutritive value, tannins profile and in vitro digestibility of Neolamarckia cadamba leaves silage. Journal of animal physiology and animal nutrition. 102(6): 1429-1436.

Jafari S, Ebrahimi M, Goh YM, Rajion MA, Jahromi MF and Al-Jumaili WS 2018. Manipulation of rumen fermentation and methane gas production by plant secondary metabolites (saponin, tannin and essential oil): a review of ten-year studies. Annals of Animal Science.

Jafari S, Goh YM, Rajion MA, Jahromi MF, Ahmad YH and Ebrahimi M 2017. Papaya (Carica papaya) leaf methanolic extract modulates in vitro rumen methanogenesis and rumen biohydrogenation. Animal Science Journal. 88(2): 267-276.

Jafari S, Meng GY, Rajion MA, Jahromi MF and Ebrahimi M 2016. Manipulation of rumen microbial fermentation by polyphenol rich solvent fractions from papaya leaf to reduce green-house gas methane and biohydrogenation of C18 PUFA. Journal of agricultural and food chemistry. 64(22): $4522-4530$.

Jiao P, Liu F, Beauchemin K and Yang W 2017. Impact of strain and dose of lactic acid bacteria on in vitro ruminal fermentation with varying media $\mathrm{pH}$ levels and feed substrates. Animal Feed Science and Technology. 224: 1-13.

Kim JG, Ham JS, Li YW, Park HS, Huh C-S and Park B-C 2017. Development of a new lactic acid bacterial inoculant for fresh rice straw silage. Asian-Australasian journal of animal sciences. 30(7): 950.

Lengowski MB, Zuber KH, Witzig M, Möhring J, Boguhn J and Rodehutscord M 2016. Changes in Rumen microbial community composition during adaption to an in vitro system and the impact of different forages. PloS one. 11(2): e0150115.

Li X, Xu W, Yang J, Zhao H, Pan C, Ding X and Zhang Y 2016. Effects of applying lactic acid bacteria to the fermentation on a mixture of corn steep liquor and air-dried rice straw. Animal Nutrition. 2(3): 229233.

LIU J-j, LIU X-p, REN J-w, ZHAO H-y, YUAN X-f, WANG X-f, Salem AZ and CUI Z-j 2015. The effects of fermentation and adsorption using lactic acid bacteria culture broth on the feed quality of rice straw. Journal of Integrative Agriculture. 14(3): 503-513.

Nguyen TTG, Wanapat M, Phesatcha K and Kang S 2017. Effect of inclusion of different levels of Leucaena silage on rumen microbial population and microbial protein synthesis in dairy steers fed on rice straw. Asian-Australasian journal of animal sciences. 30(2): 181.

Ni K, Wang Y, Li D, Cai Y and Pang H 2015. Characterization, identification and application of lactic acid bacteria isolated from forage paddy rice silage. PloS one. 10(3): e0121967.

Oladosu Y, Rafii MY, Abdullah N, Magaji U, Hussin G, Ramli A and Miah G 2016. Fermentation quality and additives: a case of rice straw silage. BioMed research international. 2016.

Ørskov E and McDonald I 1979. The estimation of protein degradability in the rumen from incubation measurements weighted according to rate of passage. The Journal of Agricultural Science. 92(2): 499503.

Saha UK, Sonon LS, Hancock DW, Hill NS, Stewart L, Heusner GL and Kissel DE 2010. Common terms used in animal feeding and nutrition.

SAS 2003. SAS User's Guide Version 9.1. Cary, NC, USA: Statistical Analysis Institute, Inc.

Silva V, Pereira O, Leandro E, Da Silva T, Ribeiro K, Mantovani H and Santos S 2016. Effects of lactic acid bacteria with bacteriocinogenic potential on the fermentation profile and chemical composition of alfalfa silage in tropical conditions. Journal of dairy science. 99(3): 1895-1902.

Van Soest Pv, Robertson J and Lewis B 1991. Methods for dietary fiber, neutral detergent fiber, and nonstarch polysaccharides in relation to animal nutrition. Journal of dairy science. 74(10): 3583-3597.

Weinberg Z, Chen Y, Volchinski V, Sela S, Ogunade I and Adesogan A 2016. An in vitro model to study interactions between Escherichia coli and lactic acid bacterial inoculants for silage in rumen fluid. Letters in applied microbiology. 63(1): 60-65.

Zhang H, Zhang P, Ye J, Wu Y, Fang W, Gou X and Zeng G 2016. Improvement of methane production from rice straw with rumen fluid pretreatment: a feasibility study. International Biodeterioration \& Biodegradation. 113: 9-16. 
444 Zhang Q, Yang H and Yu Z 2017. Effects of sucrose, formic acid and lactic acid bacteria inoculant on quality, in vitro rumen digestibility and fermentability of drooping wild ryegrass (Elymus nutans Griseb.) silage. J. Anim. Feed Sci. 26(1): 26-32.

Zhang Y, Xin H and Hua J 2010. Effects of treating whole-plant or chopped rice straw silage with different levels of lactic acid bacteria on silage fermentation and nutritive value for lactating Holsteins. AsianAustralasian Journal of Animal Sciences. 23(12): 1601-1607.

450 
Table 1. Ingredients and chemical composition of the diets fed to the cows for in vitro study

\section{Ingredients (g/kg DM)}

Alfalfa Hay

Corn, grain

170.00

Soybean meal

133.00

Palm kernel cake

Rice Bran

Sunflower oil

Mineral Premix

Vitamin Premix

Ammonium chloride

10.00

Limestone

10.00

\section{Chemical composition (g/kg DM)}

DM (\%)

$\mathrm{CP}$

EE

NDF

419.00

ADF

253.00

$\mathrm{DM}$, dry matter; $\mathrm{CP}$, crude protein, $\mathrm{EE}$, ether extract; NDF, neutral detergent fiber; ADF, acid detergent fiber. 
bioRxiv preprint doi: https://doi org/10.1101/612556; this version posted April 17 2019. The copyright holder for this preprint (which was

not certified by peer review) is the author/funder, who has granted bioRxiv a license to display the preprint in perpetuity. It is made available under aCC-BY 4.0 International license.

Table 2. Microorganisms and sequences of the primers used in this study (Ebrahimi 2012).

\begin{tabular}{ll}
\hline Target microorganism & Primer sequences $\mathbf{( 5 ' - 3 ' )}$ \\
\hline Fibrobacter succinogenes $\mathrm{F}$ & GGTATGGGATGAGCTTGC \\
Fibrobacter succinogenes $\mathrm{R}$ & GCCTGCCCCTGAACTATC \\
Ruminococcus albus $\mathrm{F}$ & CCCTAAAAGCAGTCTTAGTTCG \\
Ruminococcus albus $\mathrm{R}$ & CCTCCTTGCGGTTAGAACA \\
Ruminococcus flavefaciens $\mathrm{F}$ & CGAACGGAGATAATTTGAGTTTACTTAGG \\
Ruminococcus flavefaciens $\mathrm{R}$ & CGGTCTCTGTATGTTATGAGGTATTACC \\
General bacteria F & CGGCAACGAGCGCAACCC \\
General bacteria R & CCATTGTAGCACGTGTGTAGCC \\
General anaerobic fungi F & GAGGAAGTAAAAGTCGTAACAAGGTTTC \\
General anaerobic fungi R & CAAATTCACAAAGGGTAGGATGATT \\
Total Protozoa F & GCTTTCGWTGGTAGTGTATT \\
Total Protozoa R & CTTGCCCTCYAATCGTWCT \\
Total methanogens F & GCTCAGTAACACGTGG \\
Total methanogens R & CGGTGTGTGCAAGGAG \\
Total archaea F & ATTAGATACCCSBGTAGTCC \\
Total archaea R & GCCATGCACCWCCTCT \\
\hline
\end{tabular}

${ }^{1} \mathrm{~F}$ : forward; ${ }^{2} \mathrm{R}$ : reverse 
Table 3. Effect of inoculation of LAB on chemical composition of ensiled rice straw (DM basis)

\begin{tabular}{|c|c|c|c|c|c|c|c|c|c|}
\hline Treatments & Day & DM & $\mathrm{CP}$ & NDF & $\mathrm{ADF}$ & $\mathrm{GE}$ & Glucose $^{1}$ & Fructose $^{1}$ & Xylose $\mathrm{e}^{1}$ \\
\hline \multirow[t]{2}{*}{ Control } & 15 & $34.8^{a}$ & $9.3^{c}$ & $69.2^{\mathrm{a}}$ & $56.2^{a}$ & $15.7^{\mathrm{a}}$ & $53.6^{\mathrm{a}}$ & $0.4^{\mathrm{a}}$ & 0.4 \\
\hline & 30 & $33.6^{\mathrm{a}}$ & $9.8^{\mathrm{c}}$ & $70.2^{\mathrm{a}}$ & $56.8^{a}$ & $15.9^{a}$ & $48.2^{b}$ & $0.4^{\mathrm{a}}$ & 0.4 \\
\hline \multirow[t]{2}{*}{ L. plantarum } & 15 & $30.5^{b c}$ & $11.8^{b}$ & $66.8^{c}$ & $53.3^{b}$ & $15.5^{\mathrm{a}}$ & $35.9^{c}$ & $0.3^{\mathrm{ab}}$ & 0.4 \\
\hline & 30 & $29.2^{\mathrm{c}}$ & $12.7^{\mathrm{a}}$ & $64.1^{d}$ & $49.4^{c}$ & $14.8^{\mathrm{ab}}$ & $12.2^{\mathrm{h}}$ & $0.1^{\mathrm{c}}$ & 0.3 \\
\hline \multirow[t]{2}{*}{ L. salivarius } & 15 & $33.2^{\mathrm{a}}$ & $11.2^{\mathrm{b}}$ & $68.9^{a}$ & $53.8^{b}$ & $15.7^{\mathrm{a}}$ & $36.1^{\mathrm{c}}$ & $0.3^{\mathrm{ab}}$ & 0.4 \\
\hline & 30 & $32.8^{\mathrm{ab}}$ & $12.1^{\mathrm{ab}}$ & $66.6^{c}$ & $51.9^{c}$ & $15.5^{\mathrm{a}}$ & $25.4^{\mathrm{f}}$ & $0.2^{\mathrm{b}}$ & 0.4 \\
\hline \multirow[t]{2}{*}{ L. reuteri } & 15 & $32.5^{\mathrm{ab}}$ & $10.9^{b c}$ & $67.6^{\mathrm{b}}$ & $53.7^{b}$ & $15.9^{a}$ & $32.7^{\mathrm{d}}$ & $0.3^{\mathrm{ab}}$ & 0.4 \\
\hline & 30 & $31.3^{b}$ & $10.9^{b c}$ & $66.6^{c}$ & $52.5^{b c}$ & $15.0^{\mathrm{a}}$ & $24.6^{f}$ & $0.2^{\mathrm{b}}$ & 0.3 \\
\hline \multirow[t]{2}{*}{ L. brevis } & 15 & $33.4^{\mathrm{a}}$ & $10.6^{b c}$ & $66.9^{c}$ & $52.9^{b c}$ & $15.3^{\mathrm{a}}$ & $33.2^{\mathrm{d}}$ & $0.3^{\mathrm{ab}}$ & 0.4 \\
\hline & 30 & $32.4^{\mathrm{ab}}$ & $10.9^{b c}$ & $66.6^{c}$ & $50.6^{c}$ & $15.1^{\mathrm{a}}$ & $30.4^{\mathrm{e}}$ & $0.2^{\mathrm{b}}$ & 0.3 \\
\hline \multirow[t]{2}{*}{ S. bovis } & 15 & $32.6^{\mathrm{ab}}$ & $12.4^{\mathrm{a}}$ & $67.5^{b}$ & $52.1^{b c}$ & $15.7^{\mathrm{a}}$ & $34.6^{\mathrm{cd}}$ & $0.3^{\mathrm{ab}}$ & 0.3 \\
\hline & 30 & $31.5^{b}$ & $12.5^{\mathrm{a}}$ & $64.8^{d}$ & $50.8^{c}$ & $15.3^{\mathrm{a}}$ & $19.7^{\mathrm{g}}$ & $0.2^{\mathrm{b}}$ & 0.3 \\
\hline SEM & - & 0.60 & 0.43 & 0.46 & 0.97 & 0.65 & 0.83 & 0.05 & 0.08 \\
\hline
\end{tabular}

${ }^{1}$ Unit: $\mathrm{mg} / \mathrm{g}$

DM, dry matter; CP, crude protein; NDF, neutral detergent fiber; ADF, acid detergent fiber; GE, gross energy.

Means in each column with different superscripts are significantly different $(\mathrm{P}<0.05)$.

SEM, standard error of the mean. 
Table 4. Effects of inoculation of LAB on fermentation quality of ensiled rice straw

\begin{tabular}{|c|c|c|c|c|c|c|c|c|}
\hline & $\begin{array}{l}\mathrm{D} \\
\mathrm{a} \\
\mathrm{y}\end{array}$ & $\mathrm{pH}$ & $\begin{array}{l}\text { Lactic } \\
\text { acid } \\
(\mathrm{mM})\end{array}$ & $\begin{array}{l}\text { Acetic } \\
\text { acid } \\
(\mathrm{mM})\end{array}$ & $\begin{array}{l}\text { Propioni } \\
\text { c acid } \\
(\mathrm{mM})\end{array}$ & $\begin{array}{l}\text { Butyric } \\
\text { acid } \\
(\mathrm{mM})\end{array}$ & $\begin{array}{l}\mathrm{NH}_{3}-\mathrm{N} \\
(\%)\end{array}$ & $\begin{array}{l}\text { LAB } \\
(\log \\
\mathrm{cfu} / \mathrm{g}) \\
\end{array}$ \\
\hline & 1 & & & & & & & \\
\hline \multirow[t]{2}{*}{ Control } & $\begin{array}{l}5 \\
3\end{array}$ & $5.6^{\mathrm{a}}$ & $5.1^{\mathrm{f}}$ & $10.5^{\mathrm{e}}$ & $1.3^{\mathrm{b}}$ & $5.5^{\mathrm{a}}$ & 0.05 & $5.2^{\mathrm{c}}$ \\
\hline & $\begin{array}{l}0 \\
1\end{array}$ & $5.6^{\mathrm{a}}$ & $9.4^{\mathrm{e}}$ & $11.6^{\mathrm{e}}$ & $1.6^{\mathrm{b}}$ & $4.6^{\mathrm{a}}$ & 0.05 & $5.8^{c}$ \\
\hline \multirow[t]{2}{*}{ L. plantarum } & $\begin{array}{l}5 \\
3\end{array}$ & $5.2^{\mathrm{ab}}$ & $19.6^{c}$ & $20.8^{b}$ & $1.9^{\mathrm{ab}}$ & $1.7^{\mathrm{cd}}$ & 0.04 & $6.6^{b c}$ \\
\hline & $\begin{array}{l}0 \\
1\end{array}$ & $4.4^{b}$ & $36.9^{a}$ & $24.1^{\mathrm{a}}$ & $2.9^{\mathrm{a}}$ & $1.7^{\mathrm{cd}}$ & 0.05 & $8.8^{\mathrm{a}}$ \\
\hline \multirow[t]{2}{*}{ L. salivarius } & $\begin{array}{l}5 \\
3\end{array}$ & $5.4^{\mathrm{a}}$ & $14.6^{\mathrm{d}}$ & $13.4^{\mathrm{d}}$ & $1.2^{\mathrm{b}}$ & $3.3^{\mathrm{b}}$ & 0.05 & $6.5^{\mathrm{bc}}$ \\
\hline & $\begin{array}{l}0 \\
1\end{array}$ & $4.8^{\mathrm{b}}$ & $22.4^{\mathrm{bc}}$ & $19.1^{\mathrm{bc}}$ & $1.3^{\mathrm{b}}$ & $2.4^{\mathrm{b}}$ & 0.05 & $7.3^{\mathrm{b}}$ \\
\hline \multirow[t]{2}{*}{ L. reuteri } & $\begin{array}{l}5 \\
3\end{array}$ & $5.5^{\mathrm{a}}$ & $15.5^{\mathrm{d}}$ & $14.2^{\mathrm{d}}$ & $1.5^{\mathrm{b}}$ & $2.2^{\mathrm{c}}$ & 0.05 & $6.4^{\mathrm{bc}}$ \\
\hline & $\begin{array}{l}0 \\
1\end{array}$ & $4.8^{\mathrm{b}}$ & $26.6^{\mathrm{b}}$ & $17.4^{\mathrm{c}}$ & $2.1^{\mathrm{ab}}$ & $2.1^{\mathrm{c}}$ & 0.06 & $7.1^{\mathrm{b}}$ \\
\hline \multirow[t]{2}{*}{ L. brevis } & $\begin{array}{l}5 \\
3\end{array}$ & $5.3^{\mathrm{a}}$ & $16.9^{c}$ & $14.4^{\mathrm{d}}$ & $1.4^{\mathrm{b}}$ & $2.6^{\mathrm{b}}$ & 0.05 & $6.6^{b c}$ \\
\hline & $\begin{array}{l}0 \\
1\end{array}$ & $4.9^{b}$ & $24.1^{b}$ & $18.1^{\mathrm{c}}$ & $1.7^{\mathrm{b}}$ & $2.1^{\mathrm{c}}$ & 0.05 & $7.3^{\mathrm{b}}$ \\
\hline \multirow[t]{2}{*}{ S. bovis } & $\begin{array}{l}5 \\
3\end{array}$ & $5.3^{\mathrm{a}}$ & $19.9^{c}$ & $19.5^{\mathrm{bc}}$ & $1.6^{\mathrm{b}}$ & $1.7^{\mathrm{cd}}$ & 0.04 & $6.8^{b c}$ \\
\hline & 0 & $4.3^{\mathrm{b}}$ & $35.7^{\mathrm{a}}$ & $22.5^{\mathrm{ab}}$ & $2.5^{\mathrm{a}}$ & $1.2^{\mathrm{d}}$ & 0.05 & $8.2^{\mathrm{ab}}$ \\
\hline SEM & - & 0.31 & 1.14 & 0.88 & 0.53 & 1.01 & 0.004 & 0.48 \\
\hline
\end{tabular}

Means in each column with different superscripts are significantly different $(\mathrm{P}<0.05)$.

SEM, standard error of the mean. 
Table 5. Effects of inoculation of LAB on in vitro rumen fermentation

\begin{tabular}{|c|c|c|c|c|c|c|c|c|c|c|c|c|c|c|}
\hline Treatments & Day & DMD & Total gas & $\mathrm{pH}$ & $\mathrm{NH}_{3}-\mathrm{N}$ & Total VFA (mM) & Acetic acid & Propionic acid & $\mathrm{CH}_{4}$ & $\mathrm{CH} 4 /$ total gas & $\mathrm{a}$ & $\mathrm{b}$ & $\mathrm{c}$ & $\mathrm{a}+\mathrm{b}$ \\
\hline \multirow[t]{2}{*}{ Control } & 15 & $21.4^{\mathrm{f}}$ & $45.5^{\mathrm{a}}$ & 6.9 & 14.3 & $65.6^{\mathrm{g}}$ & $45.5^{\mathrm{g}}$ & $13.6^{\mathrm{a}}$ & $7.8^{\mathrm{a}}$ & $0.17^{\mathrm{a}}$ & 7.0 & $43.0^{\mathrm{cd}}$ & 0.05 & $50.0^{\mathrm{d}}$ \\
\hline & 30 & $22.2^{\mathrm{f}}$ & $45.0^{\mathrm{a}}$ & 6.9 & 15.6 & $67.5^{\mathrm{ef}}$ & $44.5^{\mathrm{g}}$ & $12.7^{\mathrm{ab}}$ & $7.9^{\mathrm{a}}$ & $0.18^{\mathrm{a}}$ & 6.0 & $44.0^{\mathrm{c}}$ & 0.05 & $50.0^{\mathrm{d}}$ \\
\hline \multirow[t]{2}{*}{ L. plantarum } & 15 & $25.4^{\text {de }}$ & $42.0^{\mathrm{bc}}$ & 6.9 & 15.3 & $74.7^{\mathrm{c}}$ & $46.1^{\mathrm{fg}}$ & $12.4^{\mathrm{b}}$ & $4.2^{c}$ & $0.10^{\mathrm{cd}}$ & 6.5 & $44.0^{c}$ & 0.05 & $50.5^{\mathrm{cd}}$ \\
\hline & 30 & $29.4^{\mathrm{a}}$ & $37.5^{\mathrm{c}}$ & 6.9 & 15.9 & $79.7^{\mathrm{a}}$ & $54.4^{\mathrm{a}}$ & $12.9^{\mathrm{ab}}$ & $4.1^{\mathrm{c}}$ & $0.11^{\mathrm{cd}}$ & 7.7 & $48.5^{a}$ & 0.05 & $56.2^{\mathrm{a}}$ \\
\hline \multirow[t]{2}{*}{ L. salivarius } & 15 & $22.4^{\mathrm{f}}$ & $43.5^{b}$ & 6.8 & 15.2 & $68.8^{\mathrm{e}}$ & $47.0^{\mathrm{f}}$ & $12.4^{\mathrm{b}}$ & $6.1^{\mathrm{b}}$ & $0.14^{\mathrm{b}}$ & 6.5 & $43.5^{\mathrm{c}}$ & 0.05 & $50.0^{\mathrm{d}}$ \\
\hline & 30 & $26.4^{\mathrm{cd}}$ & $41.0^{\mathrm{c}}$ & 6.8 & 15.8 & $76.1^{\mathrm{b}}$ & $49.7^{d}$ & $13.0^{\mathrm{ab}}$ & $5.9^{\mathrm{b}}$ & $0.14^{\mathrm{b}}$ & 6.5 & $45.5^{\mathrm{b}}$ & 0.05 & $52.0^{\mathrm{c}}$ \\
\hline \multirow[t]{2}{*}{ L. reuteri } & 15 & $22.4^{\mathrm{f}}$ & $40.5^{c}$ & 6.8 & 14.9 & $70.6^{d}$ & $46.7^{f}$ & $13.3^{\mathrm{a}}$ & $4.5^{\mathrm{c}}$ & $0.11^{\mathrm{cd}}$ & 6.5 & $43.5^{\mathrm{c}}$ & 0.05 & $50.0^{\mathrm{d}}$ \\
\hline & 30 & $26.4^{\mathrm{cd}}$ & $40.0^{\mathrm{cd}}$ & 6.8 & 15.5 & $74.5^{\mathrm{c}}$ & $51.6^{c}$ & $13.2^{\mathrm{a}}$ & $4.6^{c}$ & $0.12^{\mathrm{c}}$ & 6.0 & $45.7^{b}$ & 0.05 & $51.7^{c}$ \\
\hline \multirow[t]{2}{*}{ L. brevis } & 15 & $22.1^{\mathrm{f}}$ & $43.0^{\mathrm{b}}$ & 6.8 & 15.3 & $67.2^{\mathrm{ef}}$ & $48.3^{\mathrm{de}}$ & $12.5^{\mathrm{b}}$ & $5.2^{\mathrm{b}}$ & $0.12^{\mathrm{c}}$ & 6.25 & $42.5^{\mathrm{cd}}$ & 0.05 & $48.7^{e}$ \\
\hline & 30 & $27.4^{\mathrm{bc}}$ & $42.0^{\mathrm{bc}}$ & 6.8 & 15.6 & $78.3^{\mathrm{ab}}$ & $52.7^{b}$ & $13.6^{\mathrm{a}}$ & $5.4^{\mathrm{b}}$ & $0.13^{b c}$ & 7.5 & $46.0^{\mathrm{b}}$ & 0.05 & $53.5^{\mathrm{bc}}$ \\
\hline \multirow[t]{2}{*}{ S. bovis } & 15 & $24.4^{\mathrm{ef}}$ & $40.5^{\mathrm{c}}$ & 6.8 & 15.1 & $74.5^{\mathrm{c}}$ & $49.2^{\mathrm{d}}$ & $13.8^{\mathrm{a}}$ & $5.7^{\mathrm{b}}$ & $0.14^{\mathrm{b}}$ & 7.0 & $44.5^{\mathrm{bc}}$ & 0.05 & $51.5^{\mathrm{c}}$ \\
\hline & 30 & $28.4^{\mathrm{ab}}$ & $39.5^{\mathrm{cd}}$ & 6.8 & 15.7 & $78.9^{a}$ & $53.5^{\mathrm{ab}}$ & $13.3^{\mathrm{a}}$ & $5.2^{\mathrm{b}}$ & $0.13^{b c}$ & 6.75 & $47.5^{\mathrm{a}}$ & 0.05 & $54.2^{\mathrm{b}}$ \\
\hline SEM & - & 0.68 & 0.84 & 0.03 & 0.48 & 1.07 & 0.48 & 0.32 & 0.26 & 0.004 & 0.17 & 1.05 & 0.01 & 0.92 \\
\hline
\end{tabular}

$\mathrm{a}, \mathrm{b}, \mathrm{c}$, and $\mathrm{a}+\mathrm{b}$ were calculated from exponential equation $\mathrm{p}=\mathrm{a}+\mathrm{b}\left(1-\mathrm{e}^{\mathrm{ct}}\right)$.

$\mathrm{a}=$ gas production from the immediately soluble fraction, $\mathrm{b}=$ gas production from the insoluble fraction, $\mathrm{c}=$ gas production rate constant for the insoluble fraction $(\mathrm{b})$,

$(a+b)=$ potential extent of gas production.

DMD, dry matter digestibility; VFA, volatile fatty acid.

Means in each column with different superscripts are significantly different $(\mathrm{P}<0.05)$. 
Table 6. Effects of inoculation of LAB on in vitro rumen microbial populations

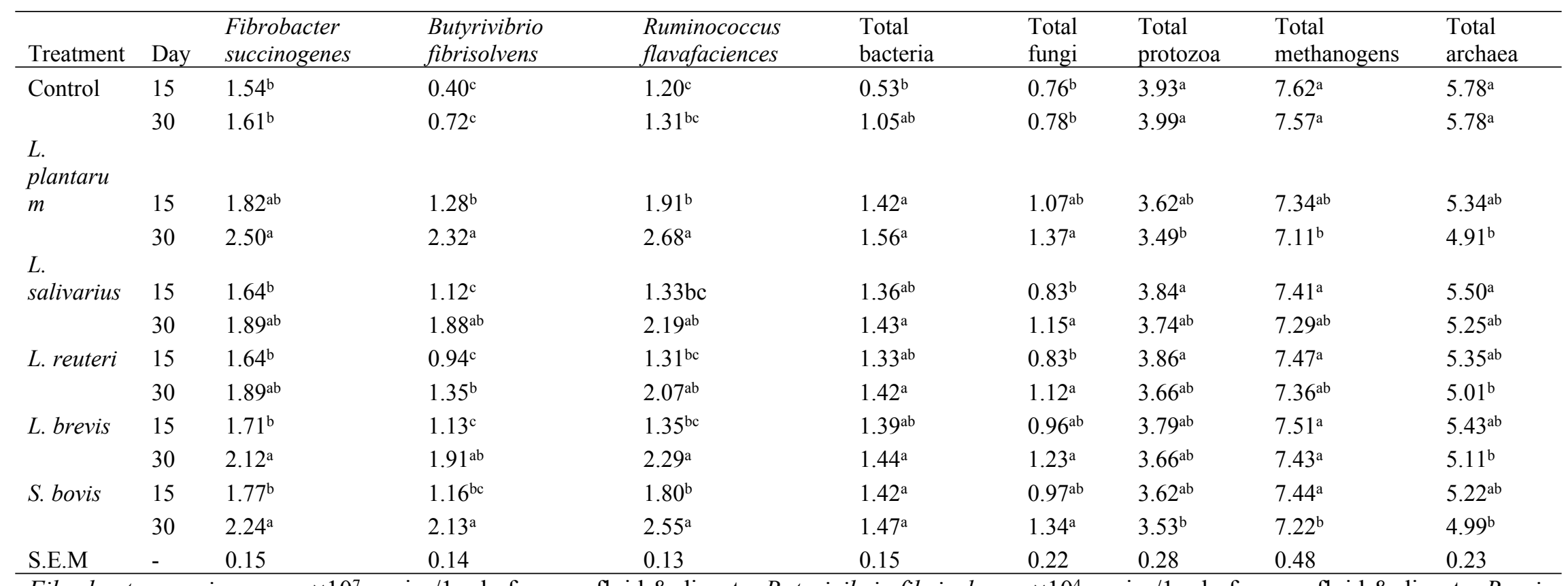

Fibrobacter succinogenes, $\times 10^{7}$ copies/ $1 \mathrm{ml}$ of rumen fluid \& digesta; Butyrivibrio fibrisolvens, $\times 10^{4}$ copies $/ 1 \mathrm{ml}$ of rumen fluid \& digesta; Ruminococcus flavafaciences, $\times 10^{6}$ copies $/ 1 \mathrm{ml}$ of rumen fluid \& digesta; Total bacteria, $\times 10^{10}$ copies $/ 1 \mathrm{ml}$ of rumen fluid \& digesta; Total fungi, $\times 10^{7}$ copies $/ 1 \mathrm{ml}$ of rumen fluid \& digesta; Total protozoa, $\times 10^{7}$ copies $/ 1 \mathrm{ml}$ of rumen fluid $\&$ digesta; Total methanogens, $\times 10^{7}$ copies $/ 1 \mathrm{ml}$ of rumen fluid \& digesta; Total archaea, $\times 10^{8}$ copies $/ 1 \mathrm{ml}$ of rumen fluid \& digesta.

Means in each column with different superscripts are significantly different $(\mathrm{P}<0.05)$.

SEM, standard error of the mean. 